\title{
PERUBAHAN KOMPOSISI KIMIA KIJING LOKAL (Pilsbryoconcha exilis) SEGAR DAN KUKUS
}

\author{
Chemical Composition Changes on Fresh and Steamed \\ Local Mussel (Pilsbryoconcha exilis) \\ Nurjanah $^{1 *}$, Agoes M. Jacoeb ${ }^{1)}$, Taufik Hidayat ${ }^{2)}$ \\ 1)Departemen Teknologi Hasil Perairan, Fakultas Perikanan dan IImu Kelautan, \\ Institut Pertanian Bogor \\ 2) Pusat Teknologi Agroindustri, Badan Pengkajian dan Penerapan Teknologi, Gedung 614 \\ LAPTIAB Puspiptek Serpong \\ *Korespondensi : inun_thp10@yahoo.com \\ Diterima 6 Oktober 2020; Disetujui 30 Oktober 2020
}

\begin{abstract}
Local mussel is a type of shellfish which is rich in minerals, fatty acids and essential amino acids and has a low cholesterol content. The local gravestone is currently only used as food by the local community which is processed by steaming. This study aims to determine the chemistry of the local gravestone. The research method used was morphometric, proximate analysis, amino acids using HPLC, fatty acids using GC, and minerals using AAS. The proximate results showed that the air and fat content decreased, while the ash, protein, and carbohydrate content increased due to the steaming process. Saturated fatty acids in local mussels tend to rise after steaming, except for palmitic which has decreased, while unsaturated fatty acids have decreased after steaming. Protein The salt-soluble content of local mussel is higher in air-soluble protein. The highest amino acid content is glutamic acid. The highest macro mineral content in local mussel meat is calcium 5,808.85 ppm, and the highest is sodium at $51.46 \mathrm{ppm}$, while the highest micro mineral is iron at $445.06 \mathrm{ppm}$, and the best is copper at 0.16 ppm . Generally, the chemical composition of local mussels on average decreased after the steaming process.
\end{abstract}

Key word: AAS, GC, HPLC, molluscs, nutritional content, processing

\begin{abstract}
ABSTRAK
Kijing lokal merupakan jenis kerang yang kaya akan mineral, asam lemak dan asam amino esensial serta memiliki kandungan kolesterol yang rendah. Kijing lokal saat ini hanya dimanfaatkan sebagai bahan pangan oleh masyarakat sekitar yang diolah dengan cara pengukusan. Penelitian ini bertujuan menentukan karakteristik kimiawi kijing lokal. Metode penelitian yang dilakukan yaitu morfometrik, analisis proksimat, asam amino menggunakan HPLC, asam lemak menggunakan GC, dan mineral dengan menggunakan AAS. Hasil proksimat menunjukkan bahwa kadar air dan lemak menurun, sedangkan kandungan abu, protein, dan karbohidrat meningkat akibat proses pengukusan. Asam lemak jenuh pada kijing lokal cendrung naik setelah pengukusan, kecuali palmitat yang mengalami penurunan, sedangkan asam lemak tak jenuh mengalami penuruan setelah dikukus. Kandungan protein larut garam pada kijing lokal lebih tinggi dari pada protein larut air. Kandungan asam amino tertinggi yaitu asam glutamat. Kandungan mineral makro tertinggi pada daging kijing lokal adalah kalsium sebesar $5.808,85 \mathrm{ppm}$, dan yang terkecil adalah natrium sebesar $51,46 \mathrm{ppm}$, sedangkan mineral mikro tertinggi adalah besi sebesar $445,06 \mathrm{ppm}$, dan yang terkecil adalah tembaga sebesar $0,16 \mathrm{ppm}$. Secara umum, komposisi kimia pada kijing lokal rata-rata mengalami penurunan setelah proses pengukusan.
\end{abstract}

Kata kunci : AAS,GC, kandungan gizi, HPLC,molusca, pengolahan 


\section{PENDAHULUAN}

Kijing lokal (Pilsbryoconcha exilis) adalah salah satu jenis kerang yang belum dimanfaatkan secara optimum, kijing ini hanya dimanfaatkan sebagai bahan pangan yang diolah dengan cara pengukusan oleh masyarakat sekitar. Kijing lokal mempunyai potensi ekonomis dan mempunyai prospek yang baik untuk dibudidayakan. Kijing lokal dapat dimanfaatkan sebagai sumber protein karena kandungan asam amino esensialnya yang tinggi sehingga mudah diserap tubuh. Potensi ekonomis lainnya yaitu sebagai bahan pangan sumber protein bagi manusia, sumber pakan ternak, industri kancing dan penghasil mutiara (Prihartini, 1999) serta komoditas budidaya perikanan darat (Suwignyo et al., 1998). Tepung dari daging kijing juga dapat dimanfaatkan sebagai bahan fortifikasi dalam pembuatan kerupuk (Mathlubi 2006). Ekstrak kijing juga menunjukkan adanya komponen bioaktif kelompok alkaloid dan flavonoid. Kijing bersifat filter feeder yang artinya mekanisme makan bergabung dengan mekanisme pernafasan. Zat-zat makanan seperti fitoplankton serta organisme mikroskopik lain akan ikut tersaring dan kemudian diubah menjadi jaringan tubuh ketika kijing menyaring air. Kijing mampu menyaring volume air sebanyak 300 $\mathrm{ml} / \mathrm{jam}$ (Turgeon, 1988). Kijing dapat menghasilkan mutiara dan proses pembentukan mutiara terjadi apabila ada benda asing yang masuk ke dalam lapisan mantel, sebagai kegiatan penolakan dan untuk melindungi dirinya. Benda asing tesebut akan dibungkus dalam suatu kantong yang terbentuk karena proses pertumbuhan ephithelium mantel yang secara terus-menerus melapisi benda asing tesebut, sehingga terbentuklah mutiara (Suwignyo et al., 1984).

Kijing umumnya dikonsumsi dengan cara dimasak secara tradisional yaitu dikukus. Pengolahan panas merupakan salah satu cara yang telah dikembangkan untuk memperpanjang umur simpan bahan pangan. Pengolahan ini dapat menghasilkan produk pangan dengan sifat-sifat yang diinginkan yaitu aman, bergizi, dan dapat diterima dengan baik secara sensori maupun kimia. Pengolahan juga dapat menimbulkan hal sebaliknya yaitu menghasilkan senyawa toksik sehingga menjadi kurang atau tidak aman, kehilangan zat-zat gizi dan perubahan sifat sensori ke arah perubahan yang kurang disukai dan kurang diterima. Metode pengolahan yang biasa dilakukan dalam rumah tangga adalah pengukusan (Harris dan Karmas, 1989).

Kandungan asam amino, asam lemak, vitamin dan mineral makro maupun mikro pada kijing perlu diketahui informasinya secara komperhensif. Beberapa hasil penelitian menjelaskan keunggulan kerang pada aspek gizi, diantaranya karakteristik kimiawi kerang tahu, salju, dan keong macan (Abdullah et al., 2017; Abdullah et al, 2016; Nurjanah et al. 2015b ;Nurjanah et al. 2015c), kerang bulu (Abdullah et al. 2013), dan kupang merah (Nurjanah et al. 2014). Informasi mengenai kandungan gizi kijing lokal ini masih sangat sedikit, padahal spesies ini memiliki kandungan gizi yang sangat baik. Penelitian ini bertujuan untuk menentukan kandungan gizi kijing lokal baik segar dan kukus.

\section{BAHAN DAN METODE}

Bahan utama yang digunakan dalam penelitian ini adalah daging kijing lokal yang diperoleh dari Situ Gede, Bogor. 
Bahan-bahan yang digunakan untuk analisis proksimat adalah akuades, $\mathrm{HCl}$, $\mathrm{H}_{2} \mathrm{SO}_{4}, \mathrm{NaOH}, \mathrm{H}_{3} \mathrm{BO}_{3}$, katalis selenium, dan pelarut heksana. Bahan-bahan yang digunakan untuk analisis mineral adalah $\mathrm{HCl}$, ammonium molibdat, ammonium vanadat, asam nitrat, dan akuades mutu tinggi. Alat-alat yang digunakan dalam penelitian ini adalah dangdang, kompor, termometer, timbangan analitik, oven, cawan porselen, desikator, tabung kjeldahl, destilator, buret, tabung reaksi, tabung kjeldahl, tabung sokhlet, gelas erlenmeyer, pemanas, tanur dan desikator.

Alat yang dihgunakan untuk pengujian asam amino adalah HPLC, sedangkan asam lemak menggunakan GC. Alat yang digunakan untuk analisis mineral antara 3 lain Atomic Absorption Spectrophotometer (AAS), glass wool, hotplate, gelas piala, labu takar, gelas ukur, cawan porselin, timbangan analitik dengan kepekaan 0,1 mg, dan alat-alat gelas khusus untuk analisis mineral dengan AAS.

\section{METODE PENELITIAN}

\section{Pengambilan dan Preparasi Kijing Lokal}

Pengambilan sampel kijing di Situ Gede, Bogor. Pengambilan sampel diambil dari tiga titik lokasi. Jumlah sampel sebanyak 30 ekor. Pengambilan sampel dilakukan dengan cara meraba dasar perairan menggunakan kaki dan mengambil kijing menggunakan tangan. Penanganan untuk menjaga kelangsungan hidup kijing lokal adalah dilakukan aklimitasi dengan cara menempatkan kijing lokal pada wadah yang berisi air dari habitatnya.

\section{Rendemen}

Rendemen dihitung sebagai persentasi bobot bagian tubuh kijing dari bobot awal. Adapun perumusan matematik adalah sebagai berkut:

$$
\text { Rendemen }(\%)=\frac{\text { Bobot contoh }(\mathrm{g})}{\text { Bobot total }} \times 100 \%
$$

\section{Pengukusan}

Pengukusan dilakukan selama 10 menit dengan suhu awal air kukusan sebesar $80^{\circ} \mathrm{C}$ yang meningkat hingga $100^{\circ} \mathrm{C}$. Kemudian kijing diambil dagingnya untuk dilembutkan menggunakan mortar. Daging yang telah lembut dimasukkan ke dalam plastik dan ditutup rapat serta diberi kode yang jelas.

\section{Prosedur Analisis \\ Analisis Proksimat (AOAC 2005)}

Analisis proksimat merupakan suatu analisis yang dilakukan untuk mengetahui komposisi kimia yang ada pada suatu bahan. Analisis proksimat meliputi: analisis kadar air, abu, kadar lemak, kadar protein dan perhitungan kadar karbohidrat dengan cara by difference.

\section{Analisis Asam Lemak (AOAC, 2005)}

Metode analisis yang digunakan memiliki prinsip mengubah asam lemak menjadi turunannya, yaitu metil ester yang memiliki sifat yang mudah menguap (volatile) sehingga dapat disuntikkan ke dalam gas chromatography. Standar asam lemak yang digunakan, yaitu kaprat (C10:0), laurat (C12:0), miristat (C14:0), palmitat (C16:0), stearat (C18:0), oleat (C18:1), linoleat (C18:2), linolenat (C18:3), EPA (C20:5), dan DHA (C22:6).

\section{Kolesterol (AOAC 2005) \\ Analisis kadar kolesterol dilakukan dengan teknik kromatografi gas. Perhitungan konsentrasi kolesterol yang terdapat dalam bahan, dilakukan}


pembuatan kurva standar dengan menggunakan kolesterol yang telah siap pakai dan mengalami perlakuan yang sama dengan sampel.

\section{Assam Amino (Abdulla et al., 2013)}

Komposisi asam amino ditentukan dengan menggunakan HPLC. Analisis asam amino dengan menggunakan HPLC terdiri atas 4 tahap, yaitu: (1) tahap pembuatan hidrolisat protein; (2) tahap pengeringan; (3) tahap derivatisasi; dan (4) tahap injeksi serta analisis asam amino.

Taurin (AOAC, 2005)

Kandungan taurin dapat dianalisis menggunakan alat HPLC.

\section{Analisis Mineral (AOAC, 2005)}

Mineral yang diuji yaitu $\mathrm{Mg}, \mathrm{Ca}, \mathrm{K}, \mathrm{Na}$, $\mathrm{Zn}, \mathrm{Cu}$, dan Fe. Sampel kijing yang telah dipreparasi dianalisis ke dalam Atomic Absorbtion Spektrophotometer (AAS merk Shimadzu tipe AA 7000 flame emission).

\section{Analisis Data}

Pengolahan data dilakukan dengan menggunakan statistik deskriptif dengan membandingkan hasil dengan studi literatur. Data diolah menggunakan Microsoft excel.

\section{HASIL DAN PEMBAHASAN}

\section{Morfometrik dan Morfologi Kijing}

Kijing memiliki bentuk tubuh yang simetri bilateral, oval memanjang atau berbentuk lidah, tidak beruas-ruas, tubuh lunak dan ditutupi mantel yang menghasilkan zat kapur, bentuk kepala jelas dengan organ pernapasan adalah paru-paru atau ingsang. Bagian samping lebih pipih, bagian depan membulat, meruncing atau bersiku di bagian belakang. Kijing memiliki warna cangkang cokelat kekuningan atau cokelat kehijauan, tipis dan transparan. Kijing memiliki cangkang yang sangat keras dan dihubungkan dengan hinge ligament yang bersambungan dengan periostrakum cangkang. Bagian dalam cangkang terdapat dua buah mantel. Bagian ujung mantel terdapat dua buah sifon yang berbeda fungsinya. Sifon ventral berfungsi sebagai alat pemasukan air (makanan), dan sifon dorsal digunakan sebagai alat pembuangan sisa-sisa metabolisme.

Kijing terdiri dari tiga lapisan utama, yaitu mantel, insang, dan organ dalam. Mantel menggantung di seluruh tubuh, dan membentuk lembaran yang luas dari jaringan yang berada di bawah cangkang. Tepi mantel menghasilkan tiga lipatan yaitu dalam, tengah, dan luar. Otot radial dan circular terdapat pada lapisan dalam, lapisan tengah berfungsi sebagai sensori, dan lapisan luar terdapat cangkang. Seluruh permukaan mantel mensekresi zat kapur (Sulistiawan, 2007). Morfologi kijing dapat dilihat pada Gambar 1.

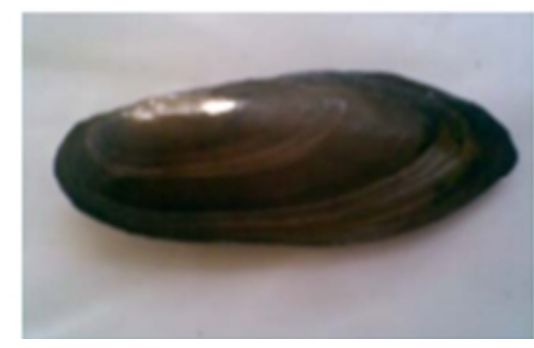

Gambar 1. Morfologi kijing (Pilsbryoconcha exilis)

Habitat hidup kijing yaitu dasar perairan berupa lumpur dengan pasir yang membentuk lapisan tanah yang tidak padat. Kijing hidup pada suhu air berkisar antara $11-29^{\circ} \mathrm{C}$ dengan derajat keasaman $(\mathrm{pH})$ antara 4,8-9,8. Kijing juga menyukai perairan yang dalam dengan kecerahan yang tinggi, mengandung bahan organik 
total yang tinggi dan substrat liat atau berlumpur. Pola distribusinya memencar dengan populasi berkelompok pada habitatnya. Kerang air tawar umumnya berdiam di dasar perairan dengan membuat lubang menggunakan kakinya yang besar dan berpindah mencari tempat yang cocok dan umumnya banyak ditemukan di perairan tenang misalnya danau. Kijing dapat mengatur tingkat metabolisme oksigen dengan baik sehingga masih dapat hidup pada keadaan kandungan oksigen dalam air sangat sedikit. Siklus hidup kijing akan sempurna jika pada periode larva (glochidia) dapat menempel (parasit temporer) pada tubuh fauna air tawar lainnya yang dijadikan sebagai inang (Suwignyo et al., 1981).

Standar mengenai kualitas dari kerang-kerangan berdasarkan SNI 3230.2: 2020 tentang persyaratan bahan baku scallop yaitu bahan baku bersih, bebas dari setiap bau yang menandakan pembusukkan dan secara organoleptik bahan baku scallop hidup memiliki karakteristik bau yang segara spesifik jenis. Kijing lokal memiliki panjang ratarata $8,23 \mathrm{~cm}$, lebar rata-rata $3,62 \mathrm{~cm}$, tinggi rata-rata $1,56 \mathrm{~cm}$ dan bobot total rata-rata sebesar $18,7 \quad$ g. Kijing mempunyai berat yang bervariasi, yaitu antara 20-40 gram. Panjangnya juga bervariasi yaitu $83-100 \mathrm{~mm}$, tinggi 15-20 $\mathrm{mm}$, lebar total kijing berkisar 33-47 mm (Pustaka IPTEK, 2008). Pertumbuhan kijing dipengaruhi oleh faktor dalam dan luar. Faktor dalam merupakan faktor yang sukar untuk dikontrol, contohnya keturunan. Sedangkan faktor luar merupakan faktor yang dapat dkontrol, diantaranya adalah makanan dan suhu. Pertumbuhan kijing sendiri dapat dilihat dari garis-garis di sekeliling umbo yang merupakan garis pertumbuhan tahunan.
Kijing yang hidup pada perairan yang relatif tenang akan tumbuh lebih baik daripada kijing yang hidup dalam perairan yang mengalir (Suwigyo et al., 1981). Hal ini karena kijing bersifat filter feeder, ketika kijing menyaring air, maka zat-zat makanan seperti fitoplankton serta organisme mikroskopik lain akan ikut tersaring dan kemudian diubah menjadi jaringan tubuh yang dapat mempengaruhi pertumbuhan kijing dari segi ukuran dan bobot.

\section{Rendemen}

Rendemen merupakan suatu parameter untuk mengetahui nilai ekonomis dan efektivitas suatu produk atau bahan. Rendemen kijing meliputi daging, jeroan dan cangkang. Proses pengolahan merupakan salah satu faktor yang memengaruhi rendemen pada suatu bahan. Rendemen kijing segar dapat dilihat pada Tabel 1.

Tabel 1. Rendemen kijing lokal segar

\begin{tabular}{cc}
\hline Rendemen $(\%)$ & Kijing lokal segar \\
\hline Cangkang & 51,93 \\
Daging & 20,71 \\
Jeroan & 27,36 \\
\hline
\end{tabular}

Kijing lokal memiliki nilai rendemen yang paling tinggi pada cangkang. Hal ini dikarenakan seluruh tubuh kijing tertutup oleh cangkang. Cangkang merupakan bagian tubuh kijing yang paling besar dan mengandung zat kapur. Tingginya kadar zat kapur $\left(\mathrm{CaCO}_{3}\right)$ dan zat tanduk pada cangkang membuat rendemen cangkang menjadi paling tinggi diantara rendemen daging dan jeroan. Nilai rendemen jeroan lebih besar daripada rendemen daging. Hal ini disebabkan karena kijing adalah hewan yang bersifat filter feeder sehingga banyak partikel makanan ataupun partikel lain yang mengendap di dalam tubuh kijing, terutama di saluran pencernaan 
dan bagian jeroan yang lainnya (Turgeon, 1988). Penyusutan rendemen pada kijing lokal terjadi karena selama proses pengukusan kandungan air yang terdapat pada cangkang, daging dan jeroan menguap sehingga terjadi pengurangan berat, selain itu daging kijing juga mengalami pengkerutan. Pada proses pengukusan terjadi kehilangan air dan lemak yang diikuti dengan terkoagulasinya serabut-serabut protein. Penyusutan rendemen yang hilang pada kijing kukus sebesar $29,73 \%$, kijing rebus sebesa $19 \%$ dibandingkan pada rendemen kijing segar.

\section{Komposisi Kimia Kijing}

Kandungan gizi secara kasar yang meliputi kadar air, abu, protein, lemak dan karbohidrat kijing segar dan kijing rebus dapat dilakukan melalui analisis proksimat. Analisis proksimat adalah suatu uji untuk mengetahui kandungan gizi yang terdapat pada bahan pangan. Hasil analisis dapat dilihat pada Tabel 2.

Komposisi kimia kijing segar dan kukus pada penelitian ini mengalami perubahan. Kadar air dan lemak mengalami penurunan menjadi $71,72 \%$ (bb) dan 0,89\% (bb). Sedangkan untuk kadar protein dan mineral mengalami peningkatan menjadi. $11,52 \%$ (bb) dan $3,46 \%$ (bb). Pengukusan merupakan cara memasak dengan menggunakan banyak air, tetapi air tidak bersentuhan langsung dengan produk (Harris dan Karmas, 1989). Tujuan dilakukan proses pengukusan pada kijing adalah untuk mematikan virus hepatitis yang terdapat pada kerang yang menyebabkan penyakit hepatitis infectiosa (penyakit kuning) (Budiarti, 2003). Selama proses pengukusan berlangsung terjadi penurunan kadar air dan lemak yang diikuti dengan meningkatnya kadar protein dan abu, hal ini disebabkan oleh proporsional akibat penurunan kadar air dan kadar lemak (Bender, 1997). Perubahan gizi yang terjadi saat proses pengukusan dipengaruhi beberapa faktor yaitu suhu pengukusan, lama pengukusan, luas permukaan dan jenis bahan (Wells et al., 1987). Daging kijing sebelum dan setelah pengukusan dapat dilihat pada Gambar 2.

Tabel 2 Komposisi kimia daging kijing lokal segar dan kukus

\begin{tabular}{ccccc}
\hline Parameter & \multicolumn{2}{c}{ Kijing segar (\%) } & \multicolumn{2}{c}{ Kijing kukus (\%) } \\
\cline { 2 - 5 } & Basis basah (bb) & Basis kering (bk) & Basis basah (bb) & Basis kering (bk) \\
\hline Air & 81,54 & 441,71 & 71,72 & 253,61 \\
Abu & 3,08 & 16,68 & 3,46 & 12,23 \\
Lemak & 1,08 & 5,85 & 0,89 & 3,15 \\
Protein & 8,90 & 48,21 & 11,52 & 40,74 \\
Karbohidrat & 5,40 & 29,26 & 12,41 & 43,88 \\
\hline
\end{tabular}

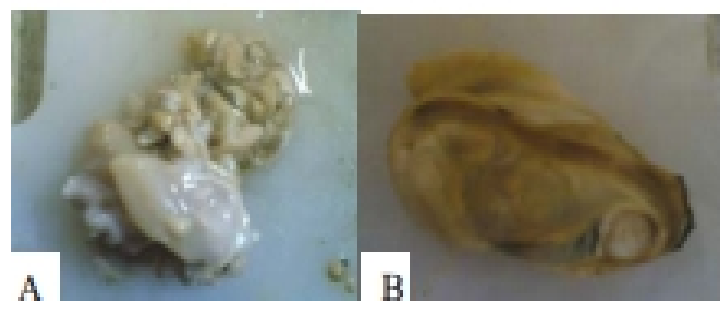

Gambar 2 Dagiing kijing segar (A), daging kijing kukus (B) 


\section{Asam Lemak}

Asam lemak merupakan senyawa organik yang terdapat dalam sel makhluk hidup yang berfungsi sebagai sumber energi, komponen struktur sel, simpanan bahan bakar metabolik, komponen pelindung dinding sel dan komponen pelindung kulit vertebrata (Girindra, 1987). Asam lemak berdasarkan tingkat kejenuhannya terdiri dari asam lemak jenuh (saturated fatty acid) dan asam lemak tidak jenuh (unsaturated fatty acid). Pembagian ini penting karena asam lemak jenuh mempunyai titik cair yang lebih tinggi dibandingkan asam lemak tidak jenuh. Asam lemak jenuh tidak memilliki ikatan rangkap antar karbonnya sedangkan asam lemak tak jenuh memiliki ikatan rangkap karbon $(\mathrm{CH}=\mathrm{CH})$. Asam lemak tak jenuh dibagi menjadi dua yaitu asam lemak tak jenuh tunggal (monounsaturated fatty acid/MUFA) dan asam lemak tak jenuh majemuk (polyunsaturated fatty acid/PUFA). Asam lemak pada daging kijing lokal segar dan kukus dapat dilihat pada Tabel 3, 4 dan 5 .

Tabel 3. Komposisi asam lemak jenuh daging kijing lokal

\begin{tabular}{lcc}
\hline $\begin{array}{l}\text { Asam lemak } \\
\text { jenuh }\end{array}$ & $\begin{array}{c}\text { kijing segar } \\
(\%)\end{array}$ & $\begin{array}{c}\text { kijing kukus } \\
(\%)\end{array}$ \\
\hline Laurat $(\mathrm{C} 12: 0)$ & 0,089 & 0,176 \\
Miristat (C14:0) & 1,023 & 1,189 \\
Palmitat (C16:0) & 28,892 & 26,228 \\
Stearat (C18:0) & 0,782 & 1,756 \\
\hline
\end{tabular}

Tabel 4. Komposisi asam lemak tidak jenuh daging kijing lokal

\begin{tabular}{ccc}
\hline $\begin{array}{c}\text { Asam lemak tidak } \\
\text { jenuh }\end{array}$ & $\begin{array}{c}\text { Kijing } \\
\text { segar(\%) }\end{array}$ & $\begin{array}{c}\text { kijing kukus } \\
(\%)\end{array}$ \\
\hline Oleat (C18:1) & 59,420 & 54,813 \\
Linoleat (C18:2) & 5,427 & 7,532 \\
Linolenat (C18:3) & 0,573 & 0,381 \\
$\quad$ Total & 65,4 & 62,726 \\
\hline
\end{tabular}

Asam lemak yang terkandung dalam daging kijing terdiri atas asam lemak jenuh, yaitu laurat, miristat, palmitat dan stearat. Asam lemak tidak jenuh tunggal, yaitu oleat, asam lemak tak jenuh jamak, yaitu linoleat, linolenat, EPA dan DHA. Keragaman komposisi asam lemak dapat dipengaruhi oleh beberapa faktor, yaitu spesies, makanan, habitat, umur dan ukuran dari kijing tersebut (Ozogul dan Ozogul, 2005). Asam lemak jenuh bermanfaat sebagai antimikroba dan asam lemak tidak jenuh bermanfaat sebagai perkembangan otak dan fungsi penglihatan. Selain itu, EPA dan DHA berfungsi sebagai pembangun sebagian besar korteks serebral otak (bagian yang digunakan untuk berpikir) dan untuk pertumbuhan normal organ (Nurjanaha et al.2015) .

Tabel 5. Komposisi asam lemak tidak jenuh majemuk berantai panjang daging kijing lokal

\begin{tabular}{ccc}
\hline $\begin{array}{c}\text { Asam lemak tidak } \\
\text { jenuh majemuk } \\
\text { berantai panjang }\end{array}$ & $\begin{array}{c}\text { Kijing segar } \\
(\%)\end{array}$ & $\begin{array}{c}\text { Kijing } \\
\text { kukus } \\
(\%)\end{array}$ \\
\hline EPA (C20:5, n3) & 0,087 & 0,072 \\
DHA (C22:6, n-3) & 0,123 & 0,103 \\
Total $(\mathrm{mg} / 100 \mathrm{~g})$ & 0,216 & 0,182 \\
\hline
\end{tabular}

\section{Kolesterol}

Kolesterol merupakan sterol yang paling dikenal oleh masyarakat. Kolesterol di dalam tubuh mempunyai fungsi ganda, yaitu disisi lain diperlukan dan disisi lain dapat membahayakan tergantung seberapa banyak kolesterol di dalam tubuh. Kolesterol adalah senyawa lemak yang dapat dihasilkan dari dalam tubuh terutama hati dan dari luar tubuh (bahan pangan) (Colpo, 2005).

Kandungan kolesterol daging kijing segar cukup rendah yaitu 83,480 $\mathrm{mg} / 100 \mathrm{~g}$. Namun setelah perlakuan pengukusan, kandungan kolesterol daging kijing menurun sebesar 72,115 $\mathrm{mg} / 100 \mathrm{~g}$. Hal tersebut dapat disebabkan karena pemberian panas pada daging kijing menyebabkan kolesterol larut bersamaan dengan terlepasnya air dari bahan dan menguapnya senyawa volatil 
yang dihasilkan, meliputi alkohol dan hidrokarbon (Wells et al., 1987). Beragamnya kandungan kolesterol kerang tergantung pada musim, area geografis, makanan dan jenis kelamin (Krzynowek dan Murphy, 1987). Kandungan kolesterol pada tubuh memiliki berbagai fungsi, yaitu sebagai bahan antara pembentukan sejumlah steroid penting, asam empedu, asam folat, hormon-hormon adrenal korteks, estrogen, androgen dan progesteron serta komponen utama pada sel otak dan saraf. Kolesterol apabila terdapat dalam jumlah terlalu banyak di dalam darah dapat membentuk endapan pada dinding pembuluh darah sehingga menyebabkan penyempitan pembuluh darah, yang dinamakan aterosklerosis. Bila penyempitan terjadi pada pembuluh darah jantung dapat menyebabkan jantung koroner dan bila terjadi pada pembuluh darah otak dapat menyebabkan penyakit serebrivaskular (Almatsier, 2006).

\section{Mineral}

Sebagian besar kandungan dalam bahan makanan terdiri $96 \%$ bahan organik dan air. Sisanya adalah unsur mineral (Winarno, 2008). Mineral dapat dibagi menjadi mineral makro dan minera mikro. Mineral makro adalah mineral yang ditubuhkan tubuh dalam jumlah yang besar sedangkan mineral mikro adalah mineral yang dibutuhkan tubuh dalam jumlah yang kecil. Kandungan mineral pada daging kijing lokal dapat dilihat pada Tabel 6.

Kandungan mineral makro tertinggi pada daging kijing lokal segar adalah kalsium sebesar 5808,85 ppm, sedangkan mineral mikro tertinggi adalah besi sebesar 445,06 ppm. Santoso et al., (2008) menyatakan bahwa diantara sekian banyak komponen gizi pada bahan pangan, mineral memainkan peranan penting dalam memelihara kelangsungan hidup organisme secara sehat dan normal. Unsur mineral merupakan salah satu komponen yang sangat diperlukan oleh makhluk hidup di samping karbohidrat, lemak, protein, dan vitamin.

\section{Asam Amino}

Protein merupakan komponen terbesar dalam jumlahnya setelah air dan merupakan bagian yang terpenting untuk manusia. Protein daging bersifat tidak stabil dan mempunyai sifat dapat berubah (denaturasi) dengan berubahnya kondisi lingkungan Berdasarkan kelarutannya, protein daging dibagi menjadi 3 yaitu protein larut air (sarkoplasma), protein larut garam (miofibril) dan protein jaringan ikat (stroma).

Tabel 6 Kandungan mineral makro dan mikro daging kijing lokal dan rebus

\begin{tabular}{ccr}
\hline Mineral & Kijing lokal segar (ppm) & Kijing lokal kukus (ppm) \\
\hline $\mathrm{Ca}$ & Mineral Makro \\
$\mathrm{K}$ & $5808,85 \pm 78,55$ & $5678,55 \pm 66,42$ \\
$\mathrm{Mg}$ & $342,15 \pm 16,04$ & $144,26 \pm 17,6$ \\
$\mathrm{Na}$ & $144,24 \pm 6,08$ & $79,15 \pm 3,6$ \\
$\mathrm{P}$ & $112,34 \pm 10,59$ & $51,46 \pm 9,57$ \\
$\mathrm{Fe}$ & $4951,78 \pm 60,48$ & $4415,51 \pm 403,26$ \\
$\mathrm{Zn}$ & Mineral Mikro \\
$\mathrm{Cu}$ & $445,06 \pm 2,35$ & $170,02 \pm 9,81$ \\
& $137,13 \pm 5,06$ & $70,12 \pm 3,55$ \\
& $0,83 \pm 0,02$ & $0,16 \pm 0,04$ \\
\hline
\end{tabular}


Kandungan PLA pada daging kijing segar sebesar 2,54\%. Dari hasil penelitian, maka terdapat korelasi antara nilai PLA dan nilai protein total pada kijing lokal. PLA yang dihasilkan memiliki nilai yang lebih kecil daripada nilai protein total atau sebesar $28,54 \%$ dari protein total. Hal ini terjadi karena protein yang terhitung hanya PLA saja tanpa mengikutsertakan PLG. Penurunan kandungan PLA terjadi pada daging kijing yang telah mengalami pengukusan yaitu menjadi $1,42 \%$. Penurunan kelarutan protein ini terjadi sebanyak $1,12 \%$. Hal ini disebabkan oleh terjadinya koagulasi dan denaturasi protein. Protein larut air tidak berperan dalam pembentukan gel dan kemungkinan mengganggu proses pembentukan gel (Suzuki, 1981).

Kandungan PLG pada daging kijing segar sebesar 3,82\%. Dari hasil penelitian, maka terdapat korelasi antara nilai PLG dan nilai protein total pada kijing lokal. PLG yang dihasilkan memiliki nilai yang lebih kecil daripada nilai protein total atau sebesar $42,92 \%$ dari protein total. Hal ini terjadi karena protein yang terhitung hanya PLG saja tanpa mengikutsertakan PLA. Penurunan kandungan protein larut garam terjadi pada daging kijing yang telah mengalami pengukusan yaitu menjadi $1,25 \%$. Penurunan kelarutan protein ini terjadi sebanyak $2,57 \%$. PLG berperan penting dalam penggumpalan dan pembentukan gel pada saat pengolahan (Ridwan 2006).

Hasil analisis asam amino daging kijing lokal menunjukkan adanya 17 asam amino pada kijing lokal yang terdiri dari 9 asam amino esensial dan 8 asam amino non esensial. Asam amino esensial meliputi: histidin, arginin, treonin, valin, metionin, isoleusin, leusin, fenilalanin dan lisin, sedangkan 8 asam amino non esensial meliputi: asam aspartat, asam glutamat, serin, glisin, alanin, prolin, tirosin dan sistein. Kandungan asam amino bebas yang terdiri dari taurin, asam glutamat, glisin, lisin dan alanin berperan penting dalam memberikan cita rasa serta flavor pada ikan dan kekerangan (Young je et al., 2005).

Kandungan asam amino esensial yang tertinggi pada kijing segar dan dikukus yaitu leusin sedangkan asam amino non esensial yang paling tinggi yaitu asam glutamat. Namun secara keseluruhan komposisi asam glutamat pada kijing lokal lebih tinggi dibandingkan asam amino lainnya yaitu sebesar $1,182 \%$. Tingginya asam glutamat pada kijing lokal menyebabkan dagingnya beraroma gurih dan berasa manis (Nurjanah et al., 2008). Kandungan asam amino kijing lokal dapat dilihat pada Gambar 3.

Asam amino pembatas pada kijing lokal segar dan kijing taiwan segar adalah sistin yaitu $0,201 \%$ pada kijing lokal. Setiap bahan pangan yang mengandung protein memiliki asam amino pembatas yaitu, asam amino yang berada pada jumlah paling sedikit. Bila dua protein yang memiliki jenis asam amino yang berbeda dikonsumsi bersama-sama, maka kekurangan asam amino dari satu protein dapat ditutupi oleh asam amino sejenis yang berlebihan pada protein lain. Dua protein tersebut saling mendukung sehingga mutu gizi dari campuran menjadi lebih tinggi (Almatsier, 2001).

Taurin merupakan senyawa tidak esensial bagi nutrien manusia karena secara internal dapat disintesis dari asam amino metionin atau sistein dan piridoksin (vitamin $\mathrm{B}_{6}$ ). Kandungan taurin pada kijing lokal sebesar $0,087 \%$ atau $87 \mathrm{mg} / 100 \mathrm{~g}$. Kandungan taurin kijing lokal masih lebih rendah bila dibandingkan dengan beberapa jenis ikan dan golongan moluska yang lain. Kandungan taurin cumi-cumi (364 mg/100 g), Short necked clam $(421 \mathrm{mg} / 100 \mathrm{~g})$ dan Oyster (1178 
$\mathrm{mg} / 100 \mathrm{~g}$ ). Namun kandungan taurin kijing lokal lebih tinggi bila dibandingkan dengan Northern shrimp atau udang (63 $\mathrm{mg} / 100 \mathrm{~g}$ ). Taurin memiliki fungsi yaitu, penghambat neurotransmiter dan sebagai bagian dari pengemulsi asam empedu. Taurin dapat mencegah diabetes, kerusakan hati akibat alkohol, menurunkan kadar kolesterol darah, menormalkan tekanan darah dan menyembuhkan masalah penglihatan (Okuzumi dan Fujii 2000). Penurunan kandungan taurin terjadi pada kijing lokal yang mengalami proses pengukusan menjadi $0,077 \%$ atau $77 \mathrm{mg} / 100 \mathrm{~g}$. Pada saat pengukusan, taurin terlepas dari daging kijing karena larut dengan air dan ikut keluar terbawa oleh uap air sehingga kandungannya berkurang. Taurin merupakan jenis asam amino yang larut dalam air (Dragnes et al., 2009).

\section{KESIMPULAN}

Perlakuan pengukusan mengakibatkan penurunan rendemen sebesar $29,73 \%$. Pengolahan panas yang diberikan pada daging kijing juga menyebabkan penurunan pada kadar air, lemak dan asam lemak pada kijing. Komposisi protein larut air dan protein larut garam serta asam amino dari kijing lokal mengalami penurunan selama proses pengukusan. Kandungan mineral makro tertinggi pada daging kijing lokal segar adalah kalsium sebesar 5808,85 ppm, sedangkan mineral mikro tertinggi adalah besi sebesar 445,06 ppm.

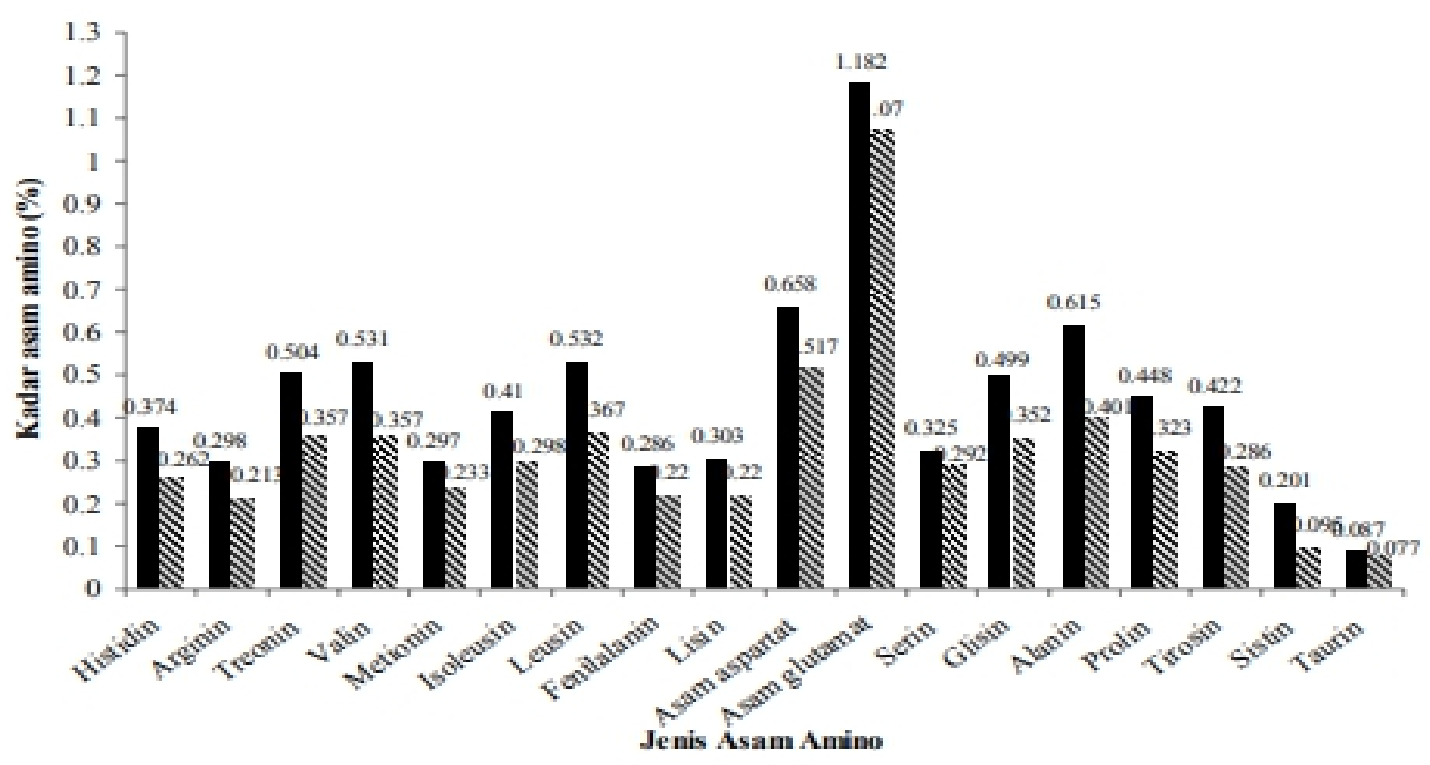

Gambar 3. Asam amino kijing lokal $\boldsymbol{\square}$ segar, $\square$ kukus

\section{DAFTAR PUSTAKA}

[AOAC] Association of Official Analitycal Chemist. 2005. Official Method of Analysis of The Association of Official Analytical of Chemist. Arlington, Virginia, USA: Published by The Association of Official Analitycal Chemist, Inc.
Abdullah A, Nurjanah, Hidayat T, Chariunisah R. 2017. Karakteristik kimiawi dari daging kerang tahu, kerang salju dan keong macan. Jurnal Teknologi Industri Pangan 28 (1), 74-84

Abdullah A, Nurjanah, Hidayat T, Gifari A. 2016. Characterize fatty acid of Babylonia spirata, Meretrix meretrix, 
Pholas dactylus. International Journal of Chemical and Biomolecular Science 2 (1), 38-42

Abdullah A, Nurjanah, Hidayat T, Yusefi Y. 2013. Profil asam amino dan asam lemak kerang bulu (Anadar antiquata). Jurnal Pengolahan Hasil Perikanan Indonesia. 16(2): 159167.

Almatsier S. 2006. Prinsip Dasar Ilmu Gizi. Jakarta: PT Gramedia Pustaka Utama.

Almatsier S. 2001. Prinsip Dasar Ilmu Gizi. Jakarta: Gramedia Pustaka Utama.

Bender AE. 1997. Countribution of meat, fish and poultry to human diet. Didalam: Shahidi F, Botta JR, editor. Seafoods: Chemistry, Processing Technology \& $Q$.

Budiarti W. 2003. Makanan Sehat. Bandung: Indonesia Publishing House.

Colpo A. 2005. LDL Cholesterol: bad cholesterol or science cholesterol. Journal of American Physicians and Surgeons 10 (3): 83-89.

Dragnes BT, Larsen R, Emhsen $\mathrm{MH}$, Maehre H, Elvevoli EO. 2009. Impact of processing on the taurine content in processed seafood and their corresponding unprocessed raw materials. Journal of Food Science and Nutrition. No. 2. Vol 60: 143-152

Girindra. 1987. Biokimia Patologi Hewan. Bogor: Fakultas Matematika dan IImu Pengetahuan Alam, Institut Pertanian Bogor

Harris RS, Karnas E. 1989. Evaluasi Gizi Pada Pengolahan Bahan Pangan. Achmadi S, penerjemah. Bandung: Penerbit ITB

Krzynowek J, Murphy J. 1987. Proximate Composition, Energy, Fatty Acid, Sodium and Cholesterol Content of Finfish, Shellfish, and their Products. America: Departement of Commerce.

Mathlubi W. 2006. Struktur karakteristik kerupuk kijing taiwan (Anadonta woodiana Lea) [skripsi]. Bogor : Fakultas Perikanan dan IImu Kelautan, Institut Pertanian Bogor.
Nurjanah ${ }^{a}$, Suseno $\mathrm{SH}$, Hidayat $\mathrm{T}$, Ekawati Y, Paramudhita P, Arifianto. 2015. Change Composisition chemical of skipjack tuna due to frying process. International Food Research Journal. 2(5): 2093-2102.

Nurjanah ${ }^{\mathrm{b}}$, Abdullah A, Hidayat T, Yulianti I. 2015. Characteristics of minerals and vitamin B12 by tiger snails, shellfish snow, Meretrix meretrix. Agricultural and Biological Sciences Journal 1 (5), 186-189

Nurjanah ${ }^{c}$, Jacoeb AM, Asren SM, Hidayat T. 2015. Minerals and heavy metals of banana puffer fish from sea of region gebang, cirebon, west java. IJPSE. 1(1):28-33.

Nurjanah, Jacoeb AM, Hidayat T, Ulma RN, Puspitasari, Hidayat T. 2014. Komposisi kimia kupang merah (Musculista senhausia) segar dan rebus. Depik. 3(3): 241-249.

Nurjanah, Kustiariyah, Rusyadi S. 2008. Karakteristik Gizi dan Potensi Pengembangan Kerang Pisau (Solen spp) di Perairan Kabupaten Pamekasan, Madura. Jurnal Perikanan dan Kelautan. Vol 13: (1) 41.

Okuzumi M, Fujii T. 2000. Nutritional and Functional Properties of Squid and Cuttlefish. Japan: National Cooperative Association of Squid Processors.

Ozogul Y, Ozogul F. 2005. Fatty acid profiles of commercially important fish species from the mediteranean, Aegean and Black Seas. J.Food Chem 100: 1634-1638

Prihartini. 1999. Jenis dan ekobiologi kerang air tawar family Unionidae (Molusca: Bivalva) beberapa situ dan kabupaten Bogor [tesis]. Bogor: Program Pascasarjana, Institut Pertanian Bogor

Pustaka IPTEK. 2008. Konsep Biomonitoring dan Ekotoksikologik: Upaya Pelestarian Sumberdaya Alam Secara Swadaya dari dan untuk Masyarakat. http: //www.iptek.net.id [15 Maret 2009].

Ridwan AA. 2006. Perubahan-perubahan protein yang diakibatkan oleh 
proses pengolahan pada daging domba. [skripsi]. Bogor: Fakultas Peternakan, Institut Bogor.

Santoso J, Nurjanah, Irawan A. 2008. Kandungan dan kelarutan mineral pada cumi cumi Loligo sp dan udang vannamei Litopenaeus Vannamei. Jurnal IImu-ilmu Perairan dan Perikanan Indonesia 15(1): 7-10.

Suwignyo P, Basmi J, Batu DTFL, Affandi R. 1981. Studi Biologi Kijing Taiwan (Anodonta woodiana Lea). Bogor: Fakultas Perikanan, Institut Pertanian Bogor.

Suwignyo S, Bambang W, Yusli W, dan Majarianti K. 1998. Avertebrata Air Jilid 1. Jakarta : Penebar swadaya.

Suwignyo P, Sugiarti S, Suwardi K. 1984. Organisma Inang Glochida Kijing
Taiwan. Bogor: IPB, Proyek Peningkatan Perguruan Tinggi.

Suzuki T. 1981. Fish and Krill Protein Processing Technology. London: Applied Science Publisher LTD

Turgeon. 1988. Class Pelecypoda. 3rd edition. Academia Press. San Diego. 985 p. http://www.biology.eku.edu. [22 Maret 2009]

Wells MR, Woods AE, Aurand LW. 1987. Food Composition and Analysis. New York: Van Nostrand Reinhold.

Winarno, F. 2008. Kimia pangan dan gizi. Bogor: M-BRIO PRESS.

Young Je J,Jam Park P,Kyo Jung W, Kwon Kim S. 2005. Amino acid changes in fermented oyster (Crassostrea gigas) sauce with different fermentation periods. J. Food Chemistry. 91:15-18. 